Historic, Archive Document

Do not assume content reflects current scientific knowledge, policies, or practices. 



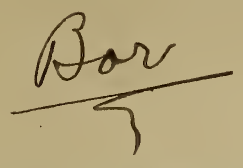

Another Spring is near. Seed and plant time will soon be with us again, and I hand you herewith my

\section{P R I C E L I S T FOR SPRING OF 1915}

If you have not already used my seeds and plants I ask you to give me a trial order and I am confident that you will be pleased with them and my treatment. I shall be glad to receive your order-large or small. Thanking you for your past trade and confidence, I am, faithfully yours, MICHAEL N. BORGO.

For Reference write to Vineland Trust Co., enclosing stamp for return.

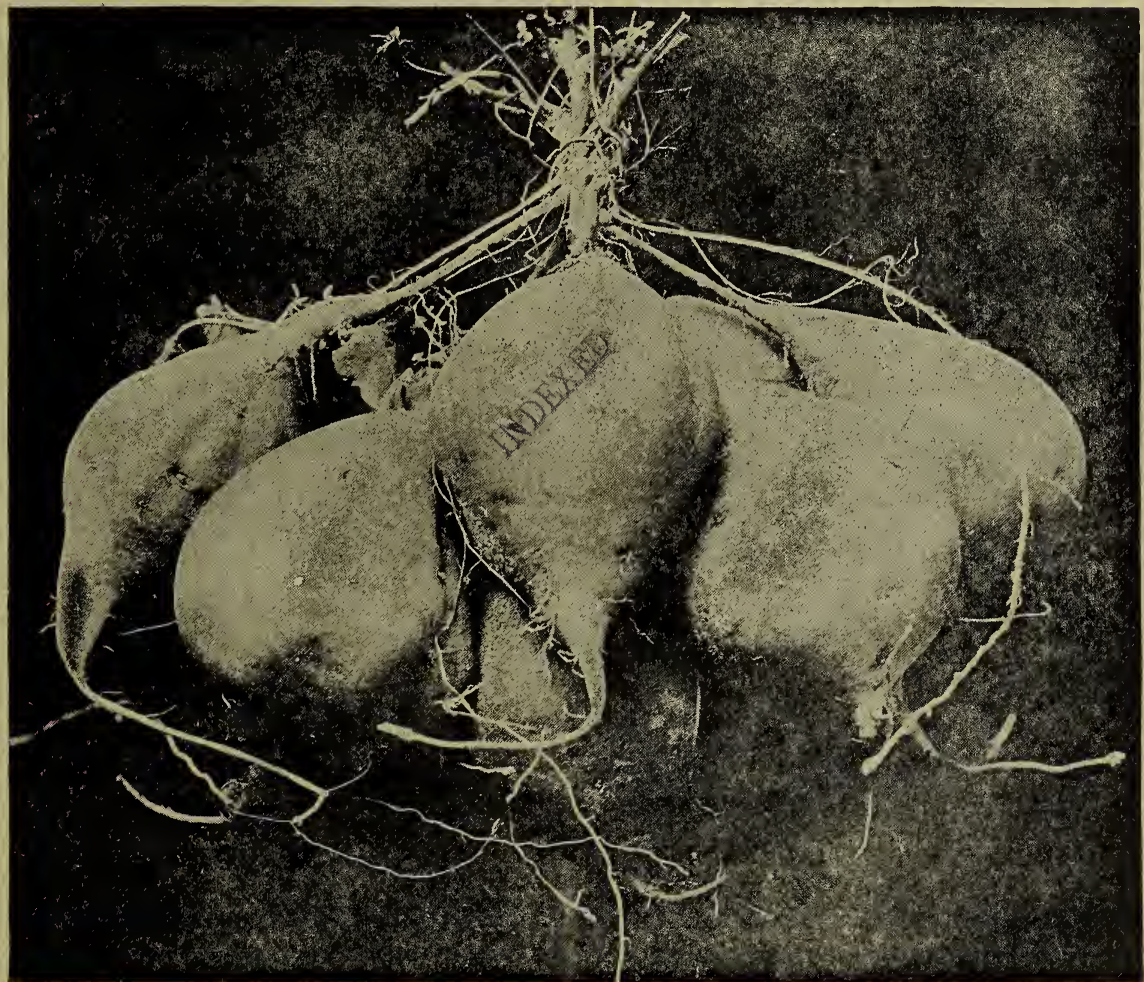

\section{MICHAEL N. BORGO}




\section{SHIPPING INSTRUCTIONS}

Please write name and address plainly, and fill all blanks perfectly. Always state how goods shall be sent, attach price to each article and add up correctly. Please do not write letters on the same sheet with the order.

We pack sweet potatoes in barrels to hold three bushels and smaller lots in hamper or box. Plants are packed with moss in baskets or boxes and paper line in cold weather and all plants and seed are delivered on board car here without extra charge.

OUR TERMS are cash with order.

IN ORDERING always state how they should be marked, by what Railroad, Freight or Express, and any information you can give.

SEND PAYMENTS by P. O. Money Order, Registered Letter or Express Order.

While we take precaution to have our seed and plants pure, and of good quality arid free from disease, we do not give any warrantee, expressed or implied, either as to quality, productiveness, or any other condition and will not be responsible for crop.

SHIPPING SEASON. Our packing season commences in the Fall about Oct. 10 and lasts as long as safe, and in the Spring about March 1st and until about May 15.

Sweet potato plants until July, Vegetable plants until Sept. 30th.

TIME TO ORDER. You should order just as soon as you receive the catalogue. By ordering early you get your order filled in time before the rush of season and get just what you want.

We have two railroad companies-New Jersey Central and West Jersey and Seashore R. R. Co. There are seven Expresses out each day and six in each day, and ten mail trains in and ten out.

\section{PACKAGES BY EXPRESS NOT PREPAID} check for my order. You will hear from me when I am in need of more. 


\section{SWEET POTATO CULTURE}

The Usual Method About the 10ih of April the potatoes are bedded in a as Practiced Here. hot bed (which may be a manure or fire heat bed.) A sandy soil is best for this. The potatoes are laid evenly over the bed about one-half to one inch apart, then cover with two or three inches of the same soil. If the heat is just right, about 75 to 90 degrees, they will begin to break ground in a week or ten days when they should be kept well watered and in two or three weeks more will prodice well rooted plants, which are pulled off by thrusting the fingers of the left hand down onto the potato and pulling the plants with the right hand. In this way several "pullings" may be taken from the same potatoes and if the soil has been properly manured, watered and cared for the last plants will be as good as the first.

These plants are set either in hills or on ridges about six or eight inches high, the rows being about three feet apart and plants from 20 to 30 inches in the row. A sandy loam is considered the best soil, but they may be grown in quite heavy soil. Prepare the ground, if not already rich, by putting a handful of fertilizer rich in potash, well mixed in each hill, or a small shovel full of compost or manure. In setting plants, if the soil is dry, it is always best to put a little water in the hole with the plant, which insures its getting a good start. They should not be set until the soil becomes warm and the weather mild. Follow with thorough clean culture. For field work a cultivator with vine turners is used whicn throws the vines on top of the ridge, or vines may be turned by hand. We allow the vines to root on top of the ridge as it seems to do no harm.

Growing Sweet Pota- Although the sweet potato finds its home in the toes in the North. warm light soils of the South, it is successfully grown in main parts of the North, even Maine is said to have produced good crops. For such places we would select a warm, sandy or gravelly soil, well protected from north and west winds if possible.

Digging and Dig in dry weather if possible, and allow to dry several hours Storing.

in tield. Put immediately in storage if to be kept in winter. Moving afterwards even from place to place in the same room will sometimes cause them to rot. A dry cellar with a stove or heater in it where the temperature can be kept about 50 or 60 degrees and air dry is one of the best places to keep Sweet Potatoes, although for large quantities storehouses are often built above ground. It is usual to leave an air space of four inches or more under the bins or boxes in which they are stored.

Cooking. Sweet potatoes may be baked, boiled or fried, the same as other potatoes. If boiled, care should be taken to have a hot fire and take up potatoes as soon as done. Served with butter or nice sweet cream they are liked by nearly everyone. The Southern Sweet Potatoes are always baked, as boiling injures their good quality. Sweet Potatoes are also used for puddings and pies.

The Vineland Sweet Potato is the king of all sweet potatoes and has the finest flavor of all. You can take them from other states and put them next to the Vineland potato and you will find that the Vineland potato has the best flavor of all. When they are shipped to market they bring from one to three dollars a barrel more than other potatoes on account of their fine bright yellow color and their wonderful flavor.

I have seen buyers in tbe markets of New York and Philadelphia looking over the potatoes, asking if they have any Vineland potatoes, if not, when will you have some, because my trade asks for them as they are the best. Therefore when you buy seed sweet potatoes you want to buy Vineland sweet potato seed and plants. They may be higher in price but you get the best for the money. Not only that, but you get the potato that has the color, shape and flavor. When you eat or sell them you can say that this is the wonderful Vineland potato which is asked for by everybody who knows of them. 
Michael N. Borgo,

Portland, Indiana.

Dear Sir:-I received the 5000 Dewberry plants by express and they are all $O, K$, and we wish to congratulate you on the packing of the plants as they are in fine shape. I will want more and will give you orders for all I need.as yours are the best plants I ever bought. J. P. Fox,

Anthens, N. Y., April 25, 1914

Dear Sir:-

I received the plants in good condition and they were O. K. I thank you very much for your prompt shipment and good packing. I was more than pleased with them. I will remember you when in need of more. Thanking you again for your prompt attention.

Yours Respectfully,

Frank Sheffield.

\section{SWEET POTATO SEED AND PLANTS}

Take Notice-Sweet potato seed is very scarce this year and I cannot furnish more than a barrel to a customer of Big Stem Jersey and of Jersey Red, but can fill all orders of Jersey Yellow providing orders are sent not later than March 25th, for large orders. Orders of five barrels or less can be filled any time. Can furnish, any quantity of No. 1 plants of all varieties.

JERSEY YELLOW.-This seems to be the preferred name for the Sweet Potato grown mainly in New Jersey. Our Vineland Fancy Strain has for years been carefully selected from the best Jersey Yellow seed, having a smooth skin, good form, color and general appearance as well as productiveness and keeping qualities, and we feel confident there can be no better seed Sweet Potatoes obtained anywhere. No. 1 will run from 1 to $11-2$ inches in diameter.

JERSEY RED.-Has the general characteristic of the Jersey Yellow. Is of a much better quality and superior for table use. Our stock is smooth and chunky.

VINELAND BUSH.-It is a true bush from the Jersey Yellow, resembling it in leaf. It forms a thick bushy top of dark green leaves and presents a most luxuriant appearance. It is as easy to cultivate and care for as a bush bean, and there are no vines to bother in digging.

BIG STEM JERSEY.-Most rapid grower and heaviest yielder of the Jersey Yellow type, and therefore growing to marketable size much earlier in the season.

\section{PRICES OF VARIETIES}

$\begin{array}{lcccccc} & \text { Peck } & \text { Bus. } & \text { Barrel } & \text { Peck } & \text { Bus. } & \text { Barrel } \\ \text { Jersey Yellow, } & \$ .75 & \$ 1.50 & \$ 3.50 & \text { Vineland Bush, } \$ 1.00 & \$ 2.00 & \\ \text { Big Stem Jersey, } & .75 & 1.50 & 3.50 \text { Jersey Reds, } & .75 & 1.50 & 3.50\end{array}$

I have a few barrels of No. 2 Seed which I will sell as long as they last at per barrel. Price subject to market changes.

Milton, Pa. 4-18 1914

Dear Sir:-I received everything O. K. Plum Farmers come to day everything in fine condition. Yours with thanks enclose find check for amount.

Yours truly,

$$
\text { O. E. Enterline. }
$$

\section{SWEET POTATO PLANTS}

Ready about May 10th.

\begin{tabular}{cccccr} 
By Mail & \multicolumn{2}{c}{ By Express } & By Mail & \multicolumn{2}{c}{ By Express } \\
$\mathbf{1 0 0}$ & $\mathbf{1 0 0}$ & $\mathbf{1 0 0 0}$ & $\mathbf{1 0 0}$ & $\mathbf{1 0 0}$ & $\mathbf{1 0 0 0}$ \\
ow .75 & .40 & $\$ 2.00$ Jersey Big Stem, Imp. .70 & .40 & $\$ 2.00$ \\
.85 & .50 & 3.00 Red Bermuda & .75 & .50 & 2.50 \\
.70 & .40 & 2.00 & & &
\end{tabular}

Fifty plants at 100 rates, and 500 at 1000 rates, of any kind. 
Mr. Michael N. Borgo,

Highland, N. J., May 8, 1914

Dear Sir:-I received the plants in good condition and they were $\mathrm{O}$. K. Will need more next year and you will hear from me again. $\quad$ Yours Respectfully,

E. V. Albertson.

Macon, Ga., March 3, 1914

Mr. Michael N. Borgo,

Dear Sir:-I received the 2000 Wilson, the 1000 Lucretia and the 1000 Asparagus Roots in good condition and they were $\mathrm{O}$. K. I was very well pleased with all the plants.

Yours Respectfully,

Geo. Brick.

\section{BLACKBERRIES}

\section{The Black Diamond Blackberries}

The Black Diamond is coming to be the leading berry for market and home use. The Black Diamond is what you should plant because there is not any berry that can take it's place, and now is the time to set out what you may want of them, do not wait until next year, or wait for your neighbor, get it yourself see for yourself, you will not make any mistake by ordering them.

The Black Diamond Blackberry was originated some years ago by George H. Liepe, from the seed of the old Evergreen, a variety of the Cut Leaf class of Blackberries. The plants are very vigorous and stocky, thus enabling them to carry to maturity their immense loads of perfect fruit. The foliage remains remarkably green till late in autumn. It is also free from rust and is not troubled with borers or rose scale.

The Fruit. The fruit is jet black and firm, and will not soften either on the bush or after it has been picked. It has an exceptionally fine flavor, spicy and melting. The berry is about the size of the Erie or Ohmer, an abundant bearer, frequently perfecting as many as 2000 berries on one vine and frequently as many as nine quarts have been gathered from a single vine.

Easily Harvested. The berries hang in large drooping clusters, well elevated above the bush, and in gathering the fruit the pickers do not come in contact with the thorns as is the case with other varieties. The plants grow to considerable size and form hedge like rows-but no clusters of fruit are hedged in; all are easily gathered from the outside of the bush.

Shipping Quality. In shipping quality it is far above all others. The Black Diamond can be shipped long distances being a hard, jet black berry that will remain firm and glossy for a week after picking. This berry always finds a ready market, as its season is later than that of any other Dewberry or Blackberry, and therefore always sells at the highest prices obtainable for such fine fruit. Its season commences August 1st, and continues to September 1 st.

Culture. The Black Diamond is very easily grown, adapted as it is to a great variety of soils. It will thrive well on poor, sandy land and yield heavy crops where nothing else will grow.

The young canes droop to the ground. Dewberry-like, and are tied to 3 -ft. stakes or wires. Culture is the same as with ordinary Blackberries.

Outlasts Any Other. Most Blackberries decline in productiveness after the fourth or fifth year. The Black Diamond will bear well for 20 years. I have a field of Black Diamonds now in its 9 th year, bearing its best crop thus far, and all strong, healthy vines.

Price. 35c each, $\$ 1.00$ doz., 50, for $\$ 3.00$ by mail; $100, \$ 5.00500, \$ 20.001000$, $\$ 35.00$ by express. 


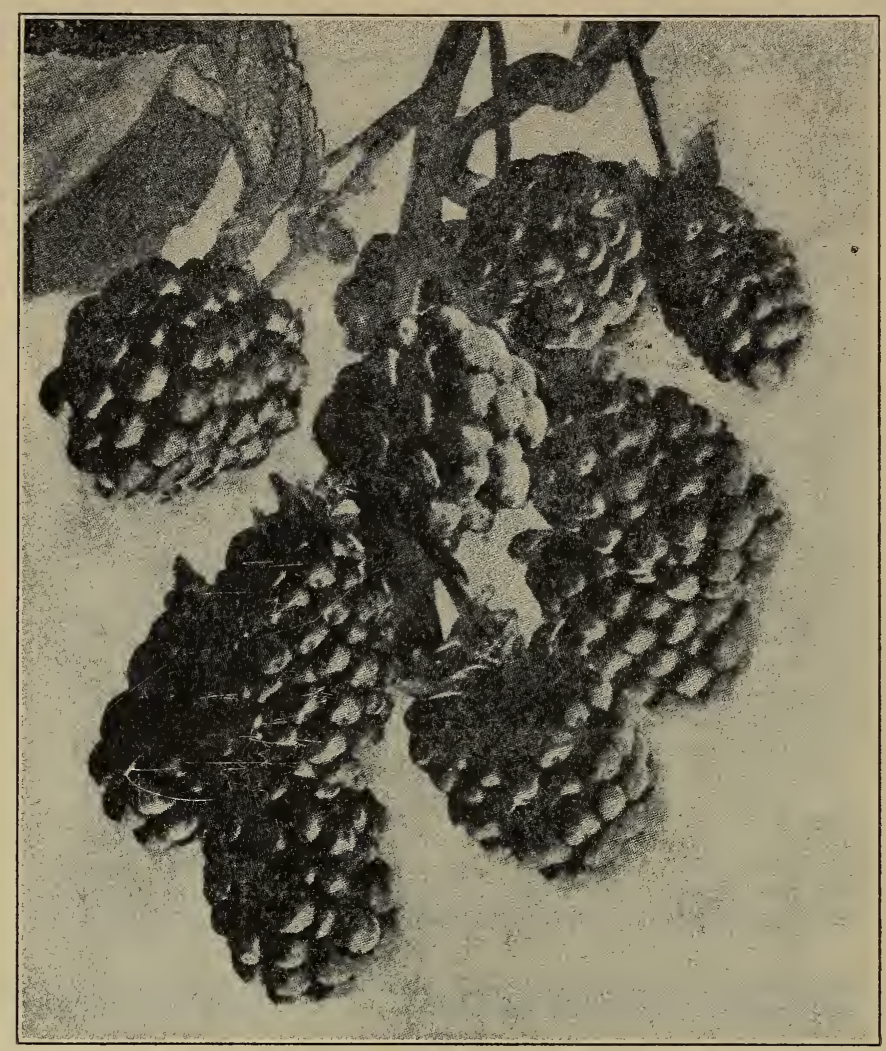

\section{THE WARD}

One of the best ever grown. I have been growing the Ward Blackberries for the last five years. It is one of the best sights I ever saw. Hedge rows were seven feet apart, canes standing four to five feet high and some two and three feet wide, and the tops were such a solid mass of green, red and black berries as to almost exclude the foliage from sight. Outside those great hedge rows was a continuous mass of berries. The ripe ones were big glossy black fellows. The canes were very hardy, never having been known to winter kill, even where the temperature went 35 and 40 below zero. The Ward does not waste itself in a lot of surplus suckers and plants. I have ten acres of Ward Blackberries in fruit which are bringing from eight to twelve cents a quart.

Of course, there are other good Blackberries, hardy of cane, productive of big berries, and Blackberries of high quality, but in no other one berry that I know can all these good qualities be found. Anyone who expects to make a new planting of Blackberries for family use should surely plant Ward, While market centers in northern sections may be sure of heavy crops yearly if they plant liberally of this grand berry.

A perfect Blackberry is Ward. Ward is a good shipper, perfectly hardy caries, no supurfluous sprou is or canes, a great yielder of large blackberries, rich and sweet-no hard cores; fruit all on outside easily harvested. 
Wilson - A very fine Blackberry, excellent quality fruit, very large and black, fine berry for market.

Ancient Britton-Strong, healthy canes are heavily laden with sweet, melting berries of medium size. Markets well.

Early Harvest-Dwarf, very early, quite productive of sweet, medium sized berries. Needs protection in the North.

Eldorado-The berries are large, jet black, borne in large clusters and ripen well together; they are very sweet, melting, have no hard core and keep for eight to ten days after picking.

Erie-Berries large and nearly round, appearing thus even larger than they really are. The canes are strong, with heavy foliage, hardy, ripens between Early Harvest and Wilson. fruitful.

Kittatinny--Large, fine berries of good quality; canes strong, erect,

Rathbun-The berries are sweet, luscious, have no core, and are firm enough to ship and handle well. The canes make a strong erect growth.

Snyder-Berries of medium size, sweet, melting. Very hardy and wonderfully productive. Leads where hardiness is a consideration. Early.

Taylor-A good succession for Snyder in cold climates. Ripens its large, luscious berries some weeks later. Vigorous, hardy, fruitful.

Mersereau-Fruit is as large, glossy and firm as Wilson. Stands shipping as well and sells for Wilson on any market. More productive than Wilson. A wonderful cropper. Plants, 30c each, $\$ 2$. doz., $100 \$ 3.50$ by mail; by express, $500 \$ 12.1000 \$ 20$.

Minnewaski-Above medium size, sweet, juicy and good quality, Early. Plants 30c each, $\$ 2$. doz., $100 \$ 3.50$ by mail; by express, $500 \$ 12$. $1000 \$ 20$.

Blowers-Fruit large; productive. A strong grower. A new favorite with many strong points.

The Logan Berry - A hybred between the Raspberry and the Blackberry. The fruit is as large as the largest Blackberry, and is produced in immense clusters. The color is clear, dark red. It partakes of the flavor of both the Blackberry and the Raspberry-mild, pleasant, vinous flavor, delicious and peculiar to this berry alone. Seeds small, soft and few. Berries very firm, and carry well. Strong grower, enormous bearer. Fruit ripens early, just after Strawberries. Not hardy north of 40 th parallel.

\section{PRICES OF BLACKBERRY PLANTS}

$\begin{array}{lrrrrllrrr} & \mathbf{1 2} & \mathbf{2 5} & \mathbf{1 0 0} & \mathbf{1 0 0 0} & & \mathbf{1 2} & \mathbf{2 5} & \mathbf{1 0 0} & \mathbf{1 0 0 0} \\ \text { Ancient Britton } & .40 & .75 & \$ 2.50 & \$ 16.00 & \text { Rathbun } & .50 & \$ 1.00 & \$ 3.00 & \$ 20.00 \\ \text { Early Harvest } & .25 & .65 & 2.00 & 15.00 & \text { Snyder } & .30 & .70 & 1.90 & 15.00 \\ \text { Eldorado } & .40 & .75 & 2.00 & 16.00 & \text { Taylor } & .35 & .75 & 2.00 & 14.50 \\ \text { Erie } & .25 & .65 & 2.00 & 14.00 & \text { Logan } & 2.00 & 5.00 & 15.00 & 100.00 \\ \text { Kittatinny } & .30 & .70 & 2.10 & 14.50 & \text { Ward } & .50 & .75 & 2.50 & 15.00 \\ \text { Wilson } & .25 & .40 & 1.00 & 7.00 & & & & & \end{array}$

Blower 35c each, $\$ 2.00$ doz., $100 \$ 6.00$ by mail, $500 \$ 17.001000 \$ 30.00$

12 and 25 plant lots by mail, others by express or freight. 


\section{RASPBERRIES}

\section{ST. REGIS}

\section{Another New Everbearing Raspberry From New Jersey}

It comes well recommended. Raspberries for four months! That's what you get when you plant St. Regis - the new everbearing variety. Moreover they are not only raspberries, but raspberries of the very highest gradein size, in brilliant crimson color, in firmness, in flavor.

The variety has been aptly termed "the early 'till late" variety; for it is the first raspberry to give ripe fruit, while it continues to produce berries without intermission until late in October.

St. Regis is of pure American blood and of ironclad hardihood; the canes enduring the severest cold uninjured and are wonderfully prolific. It's foliage never suffers by sunburn or scald; nor is it's growth impaired by the heat and drought of summer.

In addition to the bright crimson color and large size of the fruit, it is so firm and rich in sugar that it will stand shipping two hundred miles, arriving in market in first class order; and it can readily be kept in perfect condition for several days after being gathered. In brief, it is a marvel as to size, beapty and excellence. Price, $\$ 1.00$ per $25, \$ 2.00$ per $100, \$ 14.00$ per 100 . .

Welsh is a new berry about four years old and is taking it's place far ahead of a lot of other varieties and is also taking the place next to the St. Regis. The fruit is somewhat larger than the St. Regis and other varieties. The Welch makes a fine growth, the flavor is fine, the fruit is of a deep red color and very attractive.

PRICES. 25 for 90 c $100 \$ 1.75$ by mail; $500 \$ 7.001000 \$ 12.00$ by express.

The Royal Purple Raspberry.-Purple raspberries are more vigorous and productive than either reds or blacks and will succeed when reds and blacks fail. For this reason they are recommended for the average planter. The Royal is the greatest advance yet made in Purple Raspberries. It is dry, hard and firm does not crumble and can be picked before fully ripened as it comes off the stem easily. The berries are fine for home and market and the bulk of the crop comes about two weeks later than the Columbian.

PRICES. 25c each, $\$ 1.00$ per doz., by mail.

Plum Farmer is a fine big black berry. Very fine berry for home and market and a large yielding variety. The crop matures in a very short period and also very early.

PRICES. 50c per doz., postpaid; $100, \$ 2.00 ; 1000 \$ 15.00$ by express.

The Idaho Red Raspberry is a fine berry the fruit is very large, some berries attaining over one inch in diameter, and of a deep red color very attractive, fine flavor and very fine for market.

PRICES. 35c each, 5 for $\$ 1.00$ by mail; $100 \$ 3.00$ by express.

Miller Red Raspberry is a very fine berry, as good as any on the market. By express or freight, $50,75 \mathrm{c} ; 100, \$ 1.00 ; 500, \$ 4.00 ; 1000, \$ 7.00$

Brilliant. - A variety surpassing in productiveness, size, color and hardiness the famous Miller. Ripens it's fruit earlier and faster, producing bright, glossy, brilliant red berries, handsome. Being a remarkably good shipper, 
reaching market in all it's brilliancy and firmness, it finds ready sale at good prices. $\$ 1.00$ per doz., $\$ 4.00$ per 100 .

Cumberland.-Blackcap. The largest raspberry known. Selected specimens measure an inch in diameter, while they are uniformly very large. The canes are extremely hardy, having undergone a temperature of 16 degrees below zero unprotected without injury. They are immensely productive, producing annually very heavy crops. Fruit firm and in quality equal to the very best blackcaps. Season a little in advance of Gregg. 50c per doz., $\$ 3.00$ per $100, \$ 1500$ per 1000 .

Cuthbert. - A remarkably strong, hardy variety; stands the northern winters and southern summers equal to any. Berries very large, measuring three inches around; conical; rich crimson; very handsome and so firm they can be shipped hundreds of miles by rail in good condition; flavor is sweet, rich and luscious. 50c per doz., $\$ 1.50$ per $100, \$ 10.00$ per 1000 .

Columbian.-A most vigorous grower. Canes ten to fifteen feet long. It is very hardy, enduring twenty-eight degrees below zero without injury. Fruit very large, often an inch in diameter; color dark red, bordering on purple; adheres firmly to the stem, and will dry on the bush if not picked; of rich, sprightly flavor; the best for canning or evaporating. $75 \mathrm{c}$ per doz., $\$ 3.00$ per $100, \$ 20.00$ per 1000 .

Gregg.-(Black) - Has been for many years the leading market berry. Large firm, of good quality, ripening late. Exceedingly productive. 50c per doz., $\$ 1.50$ per $100, \$ 12.00$ per 1000 .

Golden Queen.--The Most desirable yellow raspberry ever introduced, especially for home use. Berries are large, of beautiful bright yellow color and of excellent quality; medium to late. $\$ 1.00$ per doz., $\$ 4.00$ per 100 .

\section{GOOSEBERRIES}

Carrie is a vigorous grower and perfectly hardy and is a heavy yielding plant. The fruit is larger than the Houghton and has a fine flavor.

Dowing is another fine fruit a strong and vigorous grower, and the berries are of an excellent quality and are fine for home or market.

Houghton is a fine berry, is grown everywhere for home and market, it is one of the healthiest of the gooseberry family and has a full crop each year.

\begin{tabular}{lcccccr} 
& By Mail & \multicolumn{5}{c}{ By Express } \\
& 12 & 25 & $\mathbf{1 0 0}$ & $\mathbf{2 5 0}$ & $\mathbf{5 0 0}$ & $\mathbf{1 0 0 0}$ \\
Houghton & .80 & $\$ 1.50$ & $\$ 4.50$ & $\$ 9.00$ & $\$ 15.00$ & $\$ 30.00$ \\
Dowing & $\$ 1.00$ & $\$ 1.75$ & $\$ 5.50$ & & & \\
Carrie & $\$ 1.50$ & $\$ 2.50$ & $\$ 8.00$ & & &
\end{tabular}

\section{CURRANTS}

Black Naples. - Bush very vigorous, upright, moderately productive; fruit varies from small to large, averaging above medium; pulp acid with strong flavor. An old and well-known variety. 
Cherry.-Bush vigorous, stocky and compact; cluster rather short, with short stems; fruit averages large; color fine, bright red; berry thin skinned, juicy and fine flavored. One of the most productive of the large currants.

Fay.-Fay's Proliflc. Bush vigorous, but not quite so strong a grower as Cherry; cluster medium to long, with rather long stems; color darker than Cherry, berry averages large; juicy and less acid than Cherry.

North Star.-Bush very vigorous, upright, somewhat spreading; clusters medium length; berries vary from small to medium or above; dark red; comparatively mild acid. Hardy and productive.

Red Dutch.-An old and well-known variety. Bush a strong, tall, upright grower, clusters average about three inches long; berries medium in size, dark red, sprightly sub-acid flavor. Productive.

Versailles.-La Versailles. Bush a vigorous somewhat spreading grower. Very similar to Cherry in habit of growth and character of fruit.

White Grape.-Bush vigorous, somewhat spreading, productive; clusters long, berries large to very large, averaging large, of very attractive color, mild flavor and good quality. A good table variety.

Price, any of above varieties of currants, strong 2 -year-old, $10 \mathrm{c}$ each, $\$ 1.00$ per doz., $\$ 7.00$ per 100 .

Mr. Michael N. Borgo,

R. F. D. No. 150, Essex, Conn., June 2, 1914

Dear Sir:-I received the sweet potato plants and am very mnch pleased with them.

Yours truly,

Mr. Geo. D. Hunt.

Ironia, N. J., June 9, 1914

Dear Sir:

Received plants in good condition. Thanks for prompt shipment.

Yours truly,

E. W. Stroud.

Dear Sir:

Trenton, N. J., 4-9 1914

The 3 bbls of Seed Sweet Potatoes received to day all in good order.

Yours with respect,

C. VanNest.

My Dear Borgo:

Mount Clemens, Mich., June 10, 1914 with you in future.

Plants received $\mathrm{O}$. $\mathrm{K}$. and in good condition. Thanks for such nice plants, will deal Respectfully,

D. S. Missnr.

Mr. Michael N. Borgo,

Greenville. Ill., 4-14-14

I received Seed Sweet Potatoes Sat. 11th, they are fine, just began to sweat a little. I would of given you a large order but I was afraid it was so far they would be spoiled.

Yours truly,

John W. Wilson. 


\section{DEWBERRIES}

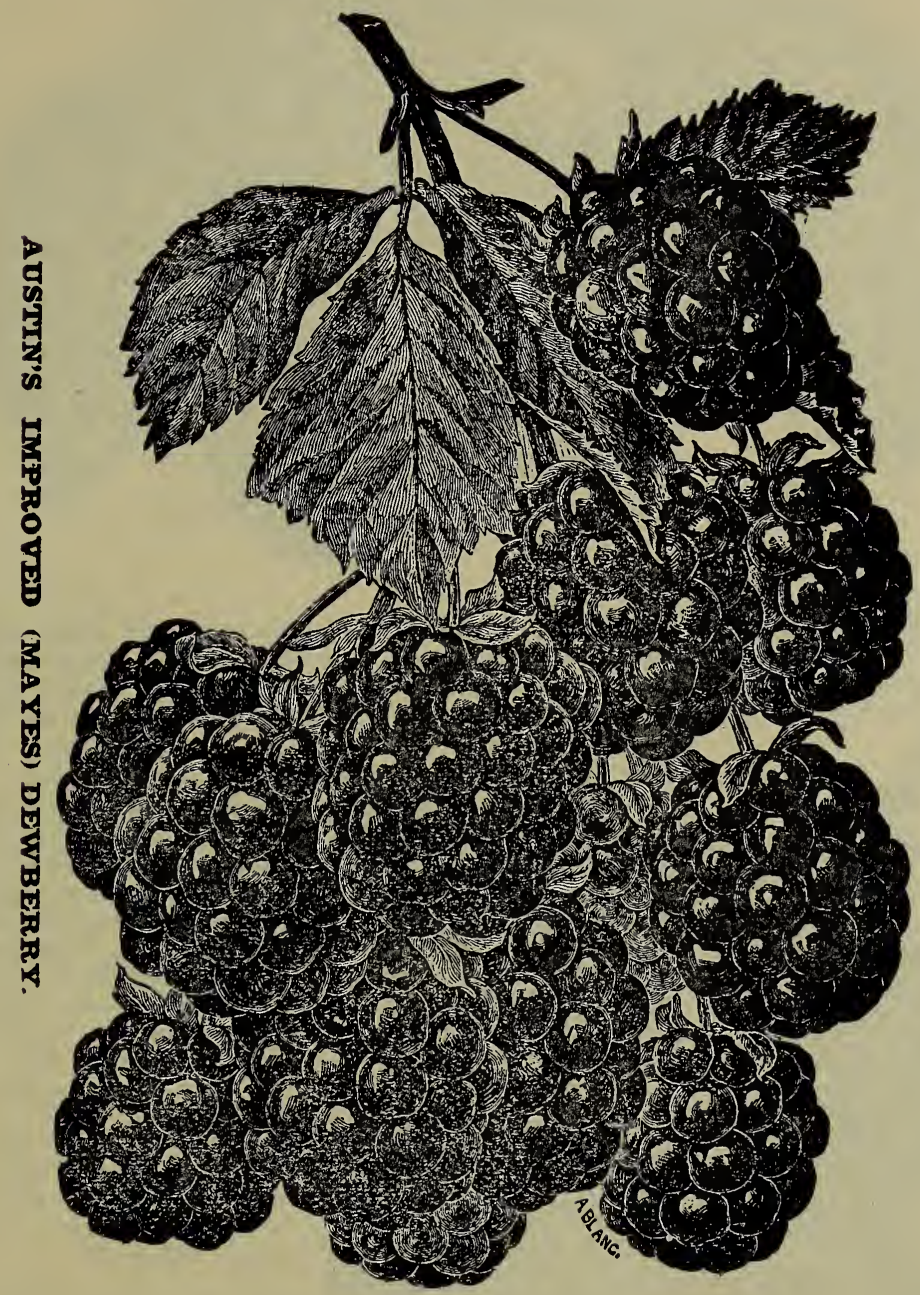

\section{Austin}

An early dewberry of excellent quality and large yield. Berries large, short and thick canes, vigorous, hardy and productive. Ripens fully a week earlier than the Lucretia. I always plant one-third of my field in this variety. It is very hardy and never fails to give a full crop. 


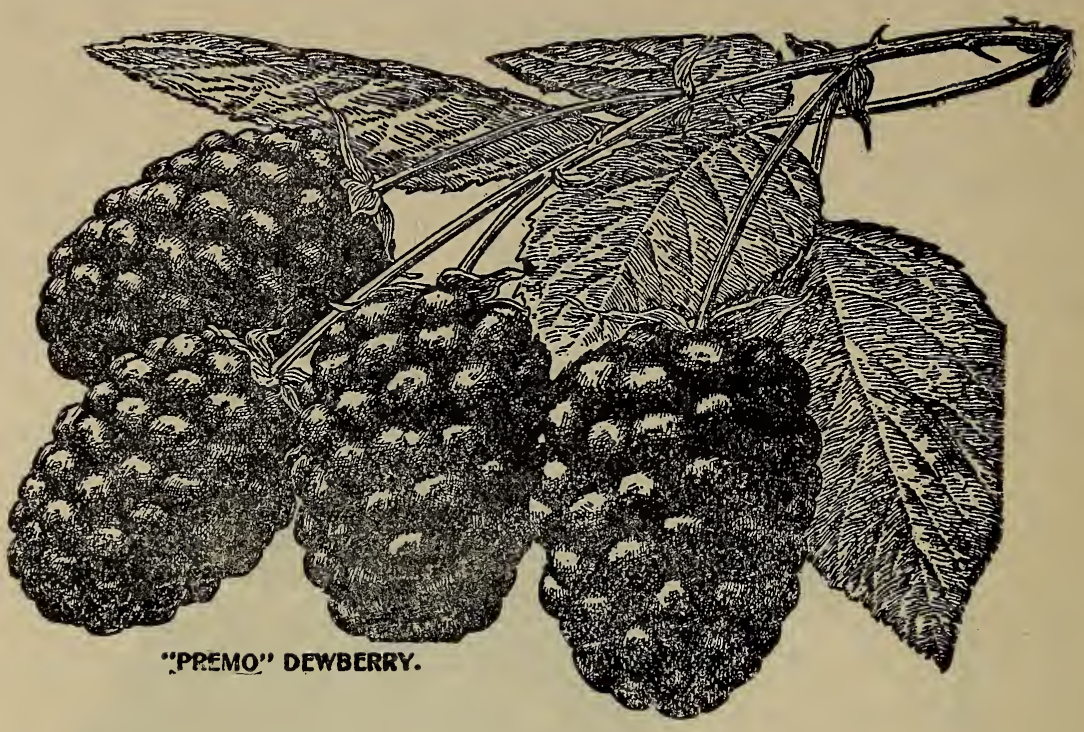

PREMO. This remarkable new Dewberry is a sport from the grand old Lucretia. The Great profitableness of the Lucretia with many growers has been tecause it was the earliest of the blackberry family to ripen. Now we have 1 remo, still earlier and larger; that means extra money in market and an earlier

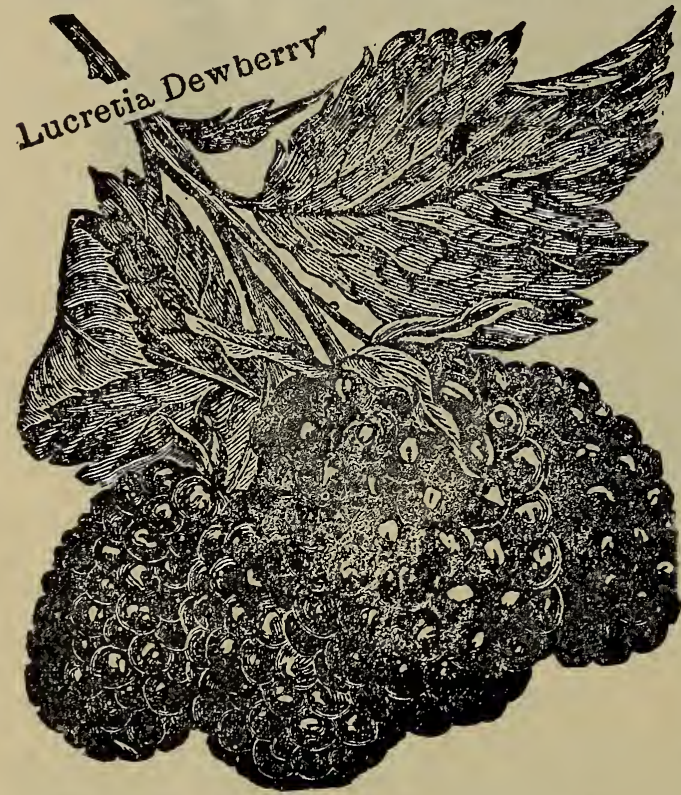

taste of delicious Dewberries for the family. Premo has imperfect flowers and so, in planting, every third or fourth row should be Lucretia; or better yet, where one is equally fond of both varieties, they can be planted in alternate rows. Remember that Premo is a delicious great blackberry that begins to ripen when the raspberry season is scarcely half over. I have been growing the Premo for the last five years and it is a very nice berry. It ripens about June 15 , and sells high in the market.

L U CRETIA. This is the best of all Dewberries, extremely hardy and very productive. Ripens a week to ten days earlier than any blackberry. Fruit large and handsome, sweet, lucious and a glossy black. The trailing habit renders winter protection very easy in severely cold climates without snow, where that protection may be necessary. 


\section{PRICES}

BY MAIL, POSTPAID

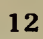

$\$ .40$

Lucretia,

.50

Premo,

\begin{abstract}
50
\end{abstract}
100

$\$ .75$

.75

.90

$\$ 1.25$

1.25

1.50

BY EXPRESS, OR FREIGHT

25

100

500

1000

$\$ .30$

$\$ 1.00$

$\$ 3.25$

$\$ 6.00$

.30

1.00

3.25

6.00

.40

1.25

5.00

8.00

Tips and Premo Suckers.

\section{CATALPA SPECIOSA}

Valuable for posts railroad ties, telephone poles, fuel, etc., etc. Makes rapid growth and is highly recommended by experiment stations and institute lecturers. We are growing the genuine Speciosa which is the only variety worth planting for above named purposes. It thrives everywhere and should be planted in all waste places, woodsides and hills too steep for cultivation. Plant Catalpa trees for large money and no work. You do not want to forget to include some in your order. Order them early.

\section{PRICES OF CATALPA SPECIOSA TREES}

100

$\$ 1.00$

1.25

2.00

2.25
500

4.00

5.00

6.00

7.00
1000

7.00

8.00

9.00

10.00

\section{ASPARAGUS ROOTS}

Palmetto is a very fine asparagus. It is quite large and fine for market and home use, and makes a heavy yield. Mr. Charles Brunner, Cumberland Co., N. J., said this is the finest he knows of. He said he has made $\$ 900$. per acre on them.

Barr's Mammouth is another good variety, about the same as the Palmetto. It is a money maker if right care is given it. Should be set in the field 4 feet each way and in good lands for good returns. Asparagus should be planted early. Every family should have 100 or more for home use.

Giant Argenteuil, is finest and most prolific of all, stock of immense size; attractive, rich and tender; comes into cutting condition earlier than most other varieties. Very reliable and a sure money maker. Comparatively free from rust and blight.

Two Year Old Barr's Mammouth

PRICES

$\begin{array}{rrr}\mathbf{1 0 0} & \mathbf{5 0 0} & \mathbf{1 0 0 0} \\ \$ .90 & \$ 2.50 & \$ 4.00 \\ .60 & 1.50 & 3.00 \\ .60 & 1.50 & 3.00 \\ .90 & 2.50 & 4.00 \\ .60 & 1.50 & 3 . C 0\end{array}$

One Year Old Barr's Mammouth,

One Year Old Giant Argenteuil,

1000

3.00

3.00

4.00

One Year Old Palmetto,

\section{RHUBARB, or Pie Plant}

Every family should have a few hills of Rhubarb as it is very fine for eating and for making pies and canning. I know of some farmers who have made $\$ 600$ per acre on it. Rhubarb brings good money in market and there is not much work to its culture. As I said before, every home should have a few 
hills for home use if not for market. If planted in the field set them 4 feet each way. You should include a few in your order I can furnish good strong roots at 50c per dozen, $\$ 2.25$ per $100, \$ 18.00$, per 1000 .

\section{HORSE RADISH} desired.

If to go by mail, add 20c per 100 . By mail postpaid at dozen rates if

Of the easiest culture. Plant the sets in moist, rich soil, small end down, with top an inch below the surface.

American. The well known sort. Doz., 35c, $100 \$ 1.00,1000 \$ 5.00$

Bohemian or Milinerkren. Of very strong growth; cuttings planted in April producing fine large "Radish" for grating the first of October. It is as white as snow when dressed. Grows to great size if left in ground until Spring and yields as much as four tons to the acre. Entirely free from all diseases and grows on any kind of soil, from heavy clay to light sand and withstands drought as well as the potato. Dozen $45 \mathrm{c} ; 100, \$ 1.50 ; 1000, \$ 7.00$.

\section{PEPPER PLANTS}

$\begin{array}{lcccr} & \mathbf{2 5} & \mathbf{1 0 0} & \mathbf{5 0 0} & \mathbf{1 0 0 0} \\ \text { New Tomato Pepper, } & .25 & .50 & \$ 2.00 & \$ 3.50 \\ \text { Bull Nose, } & .25 & .50 & 2.00 & 3.50 \\ \text { Long Red Cayenne, } & .25 & .50 & 2.00 & 3.50 \\ \text { True Red Chili, } & .25 & .50 & 2.00 & 3.50\end{array}$

\section{LETTUCE PLANTS, 3 of the Best}

$\begin{array}{lrcrr} & 25 & \mathbf{1 0 0} & \mathbf{5 0 0} & 1000 \\ \text { Bigger Big Boston, } & .15 & .50 & \$ 1.25 & \$ 2.00 \\ \text { All Season's Lettuce, } & .15 & .50 & 1.25 & 2.00 \\ \text { New Morse, } & .15 & .50 & 1.25 & 2.00 \\ 25 \text { and } 100 \text { by mail. } & \text { Over that amount by express or } & \text { freight. }\end{array}$

PRICE OF PLANTS

EARLY CABBAGE PLANTS
BY MAIL
100

.35

.35

.35

.35
BY EXPRESS

500

.90

.90

.90

.90

Extra Early Jersey Wakefield,

.25

Charleston Wakefield,

.25

All Head Early,

.25

1000

$\$ 1.50$

1.50

1.50

1.50

\section{LATE CABBAGE PLANTS}

Late Flat Dutch, BY MAIL 100

BY EXPRESS

Danish Ballhead, 


\title{
CELERY PLANTS
}

Giant Pascal

Winter Green

White Plume

Golden Self Bleaching
( 50 , by mail, $60 \mathrm{c}$, by express, $40 \mathrm{c}$

100 , by mail, $\$ 1.00$; by express, $90 \mathrm{c}$

(500, by express, $\$ 1.75 ; 1000$ for $\$ 3.00$

EARLY TOMATO PLANTS

\section{By Mail}

25

Early Earlina 25c

Early June Pink 25

\section{0}

100

$40 \mathrm{c}$

$90 \mathrm{c}$

40

\section{0}

$75 \mathrm{c}$

\section{By Express} 500

1000

$\$ 2.50$

2.50
$\$ 4.50$

4.50

\section{LATE TOMATO PLANTS}

Matchless

Stone

Success

Red Rock

\author{
$\{100$, by mail, $25 \mathrm{c}$; by express, $20 \mathrm{c}$ \\ $\{500$, by express, $75 \mathrm{c}$ \\ 1000 , by express, $\$ 1.50$
}

\section{CAULIFLOWER PLANTS}

Erfurt

Snowball

$\{100$, by mail, $75 \mathrm{c}$; by express, $50 \mathrm{c}$

$\{500$, by express, $\$ 1.75 ; 1000$, by express, $\$ 3.25$

\section{BRUSSELS SPROUTS PLANTS}

100 , by mail, $25 \mathrm{c}$; by express, $20 \mathrm{c}$

500 , by express, $\$ 1.25$

1000 , by express, $\$ 2.00$

\section{BEET PLANTS}

Eureka Extra Early

Crosby's Improved Egyptian

j00, by mail, 25c; by express, 20c

$\{500$, by express, $75 \mathrm{c}$

$\left\{\begin{array}{l}1000 \text {, by express, } \$ 1.25 \\ \text {. }\end{array}\right.$

\section{EGG PLANTS}

New York Improved

New Jersey Improved Black Beauty
$\{75$ c for 25 , by mail; $\$ 3.00$ per 100 , by express

$\{75 \mathrm{c}$ for 25 , by mail; 3.00 per 100 , by express

(75c for 25 , by mail; 3.00 per 100 by express

5 cents each for potted plants by express

\section{LEEK}

New Giant Italian, 100 for 30c; by mail; 500 for 75 c; 1000 for $\$ 1.25$; by express.

\section{Write for special prices on large lots of all plants THE BULL MOOSE POTATO}

A new potato that was introduced by us and sent out last spring for the first time. We sold a good many single specimens and quite a few in peck lots and have received many favorable letters. We let two parties near home have a quantity to grow on contract, and including what we grow ourselves, we have about 400 bushels to sell this fall and next spring. We planted 12 bushels on June $8 \mathrm{ch}$. The vines were still green and growing when a heavy freeze destroyed the vines on September 10th, and yet we harvested from the 12 bushels, 280 bushels of the finest potatoes it has ever been my pleasure to see. They created great interest and discussion among the farmers in this vicinity. The season was excessively dry and hardly any rain fell from the time they were planted until digging time in early October. It was by far the best crop 
of potatoes grown in this locality during the past season. The cooking qualities are excellent. We have reduced the price to 50 cents per tuber for selected specimens and 25 cents per tuber for potatoes as they run. There are no little ones of any account. Price per peck, $\$ 1.50$; half peck, $\$ 1.00$; bushel, $\$ 3.50$; half bushel, $\$ 2.00 ; 10$ bushels, $\$ 30.00$.

\section{THE HASTINGS}

There is just Irish enough in me to appreciate a good potato and I never have seen anything equal to the Hastings. This variety originated about 14 miles from our farm several years ago, and now is more largely grown in that locality than all other varieties combined. It is a very late potato and requires a full season to attain its greatest perfection in yield and flavor. It should be planted early for best results, and growing through a long season as it does, it takes advantage of every bit of rain that comes and is able to produce a big crop of tubers when varieties of shorter seasons will often fail. It is such a rank vigorous grower that it covers the ground with vines which are practically immune to blight and bugs. It produces potato balls every year. The tubers are white in color, roundish in shape, the popular market shape, and are very fine grained and fine flavored. Unlike most late potatoes, it is good to eat, like early varieties, as soon as dug in the fall. The flesh is very solid and tubers of ordinary size are real heavy. It is rarely you find a hollow specimen. This variety has yielded 400 bushels to the acre on ordinary soil when with the same care, on the same soil right beside them, Carman, Rural New Yorker and others produced but half the yield, Price, 1 tuber $25 \mathrm{c}$, peck $75 \mathrm{c}$, bushel $\$ 2.00$.

\section{COW PEAS}

New Era. An early maturing variety which has proved very popular and satisfactory. It is upright-growing, quick to mature, and remarkably prolific of peas. The vines cure easily, making splendid dry forage. The seed are smaller in size than the ordinary cow-pea, so that it does not require so many to seed an acre, from three-fourths to one bushel per acre will give ample seeding.

Black. This is the standard variety, and the one most largely grown in this immediate section. It is very prolific, early to mature, makes a fine growth, both of vines and leaves and a good yield of peas. It is splendid land improver, and most valuable as a forage crop, and makes an enormous yield of rich, nutritious feed.

Whippoorwill. A favorite, early, upright-growing variety, more largely used and sold than any other kind. Has brown speckled seed, which are easily gathered. Makes a good growth of vine which can be easily cut and cured as forage, Some of our customers claim that this variety is also superior in land improving qualities to any other kinds.

Clay. A favorite variety in some sections of the South. Makes a vigorous growth of vine and pods similar to the Black Pea, but is a little later in maturing. Is prolific, both in yield of peas and growth of vine. Price fluctuates. Bushel price quoted on request.

Mixed Cow-Peas. The principal varieties in the Mixed Cow-Peas we offer are the Clay, Black, Wonderfull, Whippoorwill and other Southern varieties. A great many Southern farmers prefer to sow cow-peas in mixture, as they grow thicker, producing a better crop of vines and forage than sowing single varieties alone. Where the crop is desired for soil-improving, it is really an advantage to sow these mixed peas.

Mixed Cow-Peas with Soja Beans. Where desired we can furnish Mixed Cow-Peas with Soja Beans. It is quite an advantage to sow soja beans with cow-peas. The soja beans are upright in growth and help to hold up the cow-pea vines. They are admirably adapted for cutting for hay, the cow-peas 
adding considerably to their nutritive value. The advantage of sowing cowpeas in mixture has long been recognized by our Southern growers, and the added advantage of sowing soja beans with them will make their use more popular than ever.

Price of Cow-Peas is $\$ 3.25$ per bushel. Write for prices on larger lots.

\section{GRAPE VINES}

Ives Seedling. This is one of the best grapes because it does not rot. It is a fine grape for market, also for wine. Grape juice companies will leave all others when they can get the Ives. It is very sweet when good and ripe. All growers should plant it for money making.

Mills. Black. Originated in Canada. Vines vigorous, hearty and healthy; supposed to be a cross between a native and foreign variety; bunch very large, long and should ered; berry medium to large; adhere firmly to stem flesh firm, meaty, rich and sprightly.

Green Mountain. The earliest White Grape. Bunch small to medium size, often shouldered; berries rather small, greenish white, thin skinned, tender, sweet, juicy and vigorous with delightful, sprightly, and refined flavor. Ripens very early.

Worden. A black grape that resembles Concord closely, but with more tender pulp, higher quality and ripens a week to ten days earlier. It is also a little larger in both bunch and berry than the Concord.

Campbell's Early. (Black.) Cluster large and shouldered, moderately compact, very early and productive. This is claimed to be the finest, Grape that has been produced in a long time. It makes a strong growth, with abundant thin, healthy foliage. Quality about the same as Concord.

Early Ohio. The earliest black grape known; ripens ten days to two weeks before Moore's Early. Bunch large, compact and shouldered; berry medium, covered with heavy bloon; leaves vary and perfectly healthy. Fully as hardy or more so than the Concord. A vigorous grower, very productive and of good quality. Berry adheres firmly to the stem. One of the best shippers.

Concord. Bunch and berry very large; blue-black with bloom, skin thin; crack easily; flesh sweet, pulpy, tender, good quality. Very prolific and a vigorous grower. One of the most reliable and profitable varieties for general cultivation.

\section{PRICES OF GRAPE VINES}

$\begin{array}{lcccrr} & \text { Each } & \mathbf{1 2} & \mathbf{5 0} & \mathbf{1 0 0} & \mathbf{1 0 0 0} \\ \text { Green Mountain, 1 year old } & .50 & \$ 5.00 & \$ 9.00 & \$ 15.00 & \\ \text { Campbell's Early, 2 year old } & .50 & 5.00 & 8.00 & 15.00 & \\ \text { Ives, 2 years old } & .25 & 1.00 & 2.50 & 4.00 & \$ 25.00 \\ \text { Ives, 1 year old } & .20 & .90 & 2.00 & 3.00 & 20.00 \\ \text { Early Ohio, 1 year old } & .30 & 3.00 & 5.00 & 10.00 & \\ \text { Concord, 2 year old } & .30 & 1.50 & 3.50 & 6.00 & \\ \text { Worden, 2 year old } & .30 & 1.50 & 3.50 & 6.00 & \\ \text { Mills, 1 year old } & .50 & 3.00 & 8.00 & 15.00 & \end{array}$

Order your vines at once as they are scarce

Gladiolus Bulbs. Best mixed colors, 30c doz. 100 by express $\$ 2.00$

Dahlias. Mixed colors, $25 \mathrm{c}$ doz. by mail. $\$ 1.50$ per hundred by express. Add 10 cents per dozen by mail. 
Lily of the Valley. 25 cents per dozen. $\$ 1.50$ per hundred. Add 5 cents per dozen by mail.

Tuberose. PEARL -3 for 25 cents. $\$ 1.00$ per dozeñ. Add 12 cents per dozen by mail.

\section{How to Grow a Fruit Garden}

For a smaller or larger Fruit Garden several kinds of plants can be grown at one time. Several kinds of grapes and several kinds of blackberries can be grown on the same row, and so on.

There is nothing so beautiful as when you can go out in the early Spring and see all these plants growing. There is nothing nicer than to be able to go out in the garden and gather the ripe fruit for eating. You know what it is, you know when you get it and you know it is fresh. The beauty of it all is you can have fresh fruit when you want it, and it costs you nothing but the time to gather. I would never be without it, as there is nothing so pleasing to the whole family as going into the garden and picking the ripe fruit for eating. I am offering this special bargain to introduce my plants and vines into new sections.

\section{COLLECTION No. 1.}

$\begin{array}{lcc}12 \text { Premo Dewberry } & 12 \text { Lucretia Dewberry } & 12 \text { Austin Dewberry } \\ 12 \text { Wilson Blackberry } & 25 \text { Ward Blackberry } & 10 \text { Ives Grape Vines } \\ 10 \text { Joe Strawberry } & 25 \text { Brandywine Strawberry } & 25 \text { Stevenson Prolific }\end{array}$
Asparagus, 10 Palmetto, I year roots 10 Barr's Mammouth, 1 year roots 10 Palmetto, 2 year roots. 173 Plants and Vines, all for only $\$ 2.00$

\section{COLLECTION No. 2}

\section{Premo Dewberry 25 Wilson Blackberry 20 Joe Strawberry} Asparagus, 20 Palmetto, 1 year roots

25 Lucretia Dewberry 50 Ward Blackberry

50 Brandywine Strawberry
25 Austin Dewberry 20 Ives Grape Vines 50 Stevenson Prolific 20 Palmetto, 2 year roots with order. 20 Barr's Mammouth, 1 year roots 363 Plants and Vines only $\$ 3.85$, cash

All orders F. O. B. Vineland. You make no mistake by ordering. one of the above collections. Send in your order at once before all are sold. Say whether to send by freight or express, I pack and deliver to express or freight office free of charge. Every order shall receive my personal attention. Cash with all orders. I shall be pleased to receive an order from you.
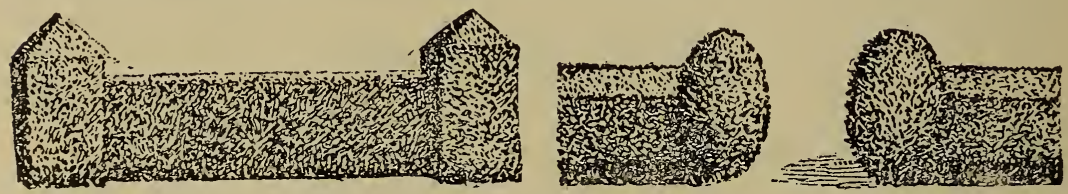

\section{CALIFORNIA PRIVET}

California Privet is one of the best hedges and beautiful shrubs on the market. It makes one of the finest hedges of all. It is hardy and its foliage is deep green. It is a very vigorous grower. This hedge is used by all Railroad Companies to beautify the office and depot yards and all other grounds. It will make a fine hedge around the lawn or anywhere you may want to plant them. I have a fine lot of good strong plants.

12 to 15 inch two year No. 1

15 to 18 inch two year No. 1

18 to 24 inch two year No. 1

2 to 3 feet
100

100

100

100
$\$ 2.00$

$2.50 \quad 1000$

$3.00 \quad 1000$

$4.00 \quad 1000$
$\$ 15.00$

18.00

25.00

35.00 


\section{DON'T WAIT FOR SHOWERS}

but keep the Planter going every day, regardless of weather. Especially adapted to NEW LAND, either stumpy or stoney. The ONLY mechanical HAND PLANT SETTER on the market, built on scientific principles, the machine being put together with rivets and solder so it should LAST FOR YEARS,

In operation the plant roots are put down to proper depth below the surface where the ground is cool and damp. You never have to wait for a shower; plants may be safely set, regardless of weather. Every farmer, truck grower and gardner should have one or more. ANY MAN, with very little practice can set 12,000 Plants each day.

The setter has a record of over 998 plants to grow per 1,000 set. Use liquid fertilizer if desired. MONEY REFUNDED in case this Planter fails to fulfill every claim we make.

SAVES IT'S COST a dozen times in a season. LIGHT, EASY WORKno stooping, easy to handle.

REASONABLE IN PRICE-only $\$ 4.50-$ Read what others say of it, and ORDER YOURS TODAY!

\section{STRAWBERRY PLANTS}

Early Jersey Giant.-The berries are large brilliant scarlet crimson color. It is a strong grower and a big yielder

Prices. 12, 60c 25, $\$ 1.0050, \$ 1.75100$. $\$ 3.00500, \$ 10.00$.

Michael Early.-One of the earliest varieties grown it is a very strong and healthy berry and fine for home and market.

Price $100,50 \mathrm{c} 500, \$ 2.001000, \$ 3.50$ by express; if to go by mail add 30c per 100 .

Senator Dunlap-This is as fine a Medium Early variety as can be found a variety that has a demand everywhere and produces an enormous crop of fine fruit and it is as fine a berry as you want for market as it will retain it's color long after being picked and therefore it is just what you want for market. The demand for this variety is very large each year. The variety you should plant for large crops and big money.

Price $100,50 \mathrm{c} 500, \$ 2.001000, \$ 3.50$ by express; if to go by mail add $30 \mathrm{c}$ per 100 .

Gandy Bell-is a strong and healthy plant maker and the plants are strong and will yield an enormous crop of fine fruit as you want and they are fine for canning and market having received more per qt. than for other varieties. I recommend the planting of this berry, it ripens the same time as Senator Dunlap, by planting the two varieties you shall not make any mistake.

Price $100,50 \mathrm{c} 500, \$ 2.001000, \$ 3.50$ by express; if to go by mail add $30 \mathrm{c}$ per 100 . 
Heritage.-An extra large berry; plants strong and healthy just the kind that will yield a large crop of fine handsome berries. Price 500, $\$ 2.251000, \$ 4.00$

Wm. Bell-is another luxuriant grower and remarkably productive. The berry has a fine shape and glossy red color and it ripens all over at once.

Price $100,50 \mathrm{c} 500, \$ 2.001000, \$ 3.50$ by express; if to go by mail add 30c per 100 .

Steven Late - is as fine a late berry as any one could want this variety makes strong vigorous plants the kind that will yield large crops of fine fruit. It ripens all over in fine shape, it is a very fine berry for canning and market.

Price $100,50 \mathrm{c} 500 \$ 2.001000 \$ 3.50$ by express; if to go by mail add 30c per 100 .

\section{PEAS}

A List of a few of the Best Varieties of Peas. EARLY

Alaska

Record Extra Early

Pilot

Grandus

Thomas Lexton

Sutton's Excelsior

$\begin{array}{ccc}\text { per } & \text { quart } & .45 \\ \text { “ } & \text { “ } & .50 \\ \text { “ } & \text { “ } & .75 \\ \text { “ } & \text { “ } & .55 \\ & & .35\end{array}$

$\begin{array}{ccr}\text { per } & \text { bushel } & \$ 6.50 \\ \text { “ } & \text { “ } & 6.75 \\ \text { “ } & \text { “ } & 13.00 \\ \text { “ } & \text { “ } & 5.50 \\ \text { “ } & \text { “ } & 7.25 \\ & & 7.50 \\ \text { “ } & \text { “ } & 7.50 \\ \text { “ } & \text { “ } & 7.00 \\ \text { “ } & \text { “ } & 12.00\end{array}$

SECOND EARLY

Standard Midseason “ “ $\quad$ “ $\quad 35$

Horsford Market Garden “ “ “ $\quad .45$

Mammoth Podded, prolific sugar “ " " $\quad .75$

12.00

If by mail add 8 cents per quart. Send your order early.

\section{MASTERS' PLANT SETTER}

and one man will set, Water and if desired Fertilize more Plants than three men can Set by hand - and every Plant is securely rooted by absorption, nature's way, so that it has a chance to grow.

Two barrels of water with one of these Setters, will insure a perfect stand of Plants on one acre, RAIN OR NO RAIN.

The Setter is durably constructed, the invention of a practical man, sold on honor-your satisfaction guaranteed.

PRICE IS REASONABLE. THERE IS

\section{NO STOOPING WHEN USING}

SETS ALL KINDS OF PLANTS

Such as Cabbage, Tobacco, Tomato, Cauliflower,

Celery, Sweet Potatoes, Sugar Beets,

Etc. and the Plants are

Set in Water and Covered at One Operation

PRICE EACH $\$ 4.50$ 